\title{
Effect of probiotics, antibiotics and herbal extracts on aeromonassp and vibriospisolated from a marketed marine fish
}

\begin{abstract}
Bacterial pathogens analysis in Lethrinus lentjana commercially available fish indicated the presence of two major fish pathogens such as Aeromonassp and Vibrio sp. In this study, the effect of antibiotics, probiotic preparations along with plant extract was investigated against four species coming under two bacterial genus A. hydrophila, A. sobriaand V. cholerae and V. damsela. Test conducted with 20 antibiotics of different types revealed the emergence of Multi Drug Resistance in all the tested organisms. Highest \% of resistance was noted in A. sobria, V. damsela and least in A. hydrophila, V. cholerae. The resistance was in the following order A. sobria, V. damsela, A. hydrophila, V. cholerae. Ineffective nature of commonly used antibiotics such as Amoxicillin, Ampicillin, Carbenicillin, Ciprofloxacin and Erythromycin against the tested organisms worrying us because which could target not only aquatic animals but also human. Attention on organic aquaculture has been on raise due to the side effects of chemicals. Examination of the effect of selected 10 herbs and 6 species of commonly used probiotic Lactic Acid Bacteria explored the presence of meager antibacterial effect. Further studies will lead to increase the efficacy of the organic inputs and to develop safe and friendly disease managing strategies. Microbial resistance to antibiotics is gaining a lot of attention in the past few years. All over the world, continuous monitoring of antibiotic resistance in microbes have been done against various drugs. Effective treatment depends on the understanding of antimicrobial resistance developed in microbes. Fish bacterial pathogens are not an exceptional for it. Marine fishes are rich of vital nutrients and transported to faraway places due to its demand among consumers. Transportation, handling, storage and distribution pave way for the contamination at higher degree in addition to its natural microflora. Resistance developed in the bacteria causing diseases in fishes could also harm human beings and could supply resistance to other human pathogens.
\end{abstract}

Keywords: antibacterial activity; plant extract; fish disease; zone of inhibition; aeromonassp; vibrio sp; antibiotics; MDR; herbs and probiotics
Volume I Issue 2 - 2015

Viswanathan S,' Chinnammal sudha R,' AmuthanM,' Rajesh R,' Suba P,' Chairman K' 'Post Graduate Department of Microbiology, Sri Paramakalyani College, India

${ }^{2}$ Department of Microbiology, M.S. University, India

Correspondence: Viswanathan S, Post Graduate Department of Microbiology, Sri Paramakalyani College, India, Email mailto:drvasanthi20I2@gmail.com

Received: April 09, 2015 | Published: August 03, 2015

\section{Introduction}

Aeromonassp and Vibrio $s p$ are a major threat in from aquaculture. Control and eradication of these bacteria are generally achieved by the usage of wide range of antibiotics. ${ }^{1-3}$ Antibiotics are substances that have the ability to kill or prevent the growth and activities of microorganisms. Antibiotics are now generally accepted as essential drugs for human and animal health and welfare. Farmed aquatic animals are safeguarded from bacterial diseases mainly using antibiotics. ${ }^{4}$ But there is an increasing danger of developing antibiotic resistant ${ }^{5}$ due to its continuous and increased use in aquaculture. ${ }^{6}$ Chemotherapy (the use of chemicals or synthetic antibiotics to treat fish diseases) should be considered as an emergency or last-resort measure. ${ }^{7}$ Although chemicals or synthetic antibiotics may reduce the incidence of several kinds of pathogens or control the abundance of facultative organisms, they also may have negative effects on desirable biota. Some chemicals may be dangerous to the use or leave undesirable or harmful residues in the cultured animals, the results of which may put the consumers of such animals at a risk. The undesirable side effects of antibiotics forced us to lead organic aquaculture, where, we depend on natural inputs like herbs and Probiotics.
Several hundred plant genera are used medicinally and vital sources for potent and powerful drugs. ${ }^{8}$ In India, nearly 500 plants are reported to have antibacterial effect due to the production of different secondary metabolites. Across the world, a huge attention is paid towards herbs for managing pathogens associated with aquaculture and its produces. ${ }^{9}$ Promising results have been documented by the usage of Probiotics in aquaculture. ${ }^{10,11}$ The beneficial effects from Probiotics are numerous involving inhibition of pathogens by occupying the binding sites, production of anti microbial compounds, improving the immune status of the host etc., Market for aquaculture Probiotics gain momentum in recent years due to their reliability and safety. In this back ground the present work has been tailored to understand the multi drug resistance development in the potent bacterial pathogens isolated from a marketed fish and to analyse the effect of selected organic aquaculture inputs over the control of pathogens.

\section{Materials and methods}

Collection of fish samples: Pink eared emperorfish (Lethrinus lentjan) was obtained from a commercial fish market in Thoothukudi, Tamil Nadu, India, during June 2014. The fish was collected individually in pre-sterilized polythene bags and transported to the laboratory in an ice chest. 


\section{Isolation of Vibrio sp and Aeromonas sp}

Fish was washed thoroughly with sterile distilled water prior to bacteriological examination. The head, tail and the gut of the fishes were removed using sterile scissors. The fish muscle samples were then homogenized in blenders, and $10 \mathrm{~g}$ of each homogenate was placed in $100 \mathrm{ml}$ of alkaline peptone water (APW) $\mathrm{pH} 8.6$, and incubated at $37^{\circ} \mathrm{C}$ for 24 hours. At the end of incubation period, two loopful of culture from pellicle of each flask (Enrichment broth APW) were then streaked on to Thiosulfate Citrate Bile Salts sucrose (TCBS) agar plates and Aeromonas isolation agar plates and incubated at $37^{\circ} \mathrm{C}$ for 24 hours for the isolation of Vibrio $s p$ and Aeromonas $s p$ respectively. ${ }^{12-16}$

\section{Identification of selected microorganisms}

The isolated strains were identified morphologically (shape, Gram's staining, and motility) and biochemically (Indole production test, citrate utilization test, methyl-red, Voges-Proskauer test, Oxidase test, catalase test, starch hydrolysis test, gelatin hydrolysis, string test) according to Bergey's manual of determinative bacteriology.

\section{Haemolytic activity}

Aeromonas $s p$ and Vibrio $s p$ producing hemolysin was tested on blood agar supplemented with $5 \%$ sheep anticoagulant blood. All the selected cultures were seeded in blood agar plates, and the plates were incubated at $37^{\circ} \mathrm{C}$ for 24 hours. Hemolytic activity was determined following by Arunagiri et al. ${ }^{13}$

\section{Screening the effect of antibiotics, probiotics and plant} extracts:

In vitro Antibiogram study: The effectiveness of 20 antibiotics from Hi-media was checked by disc diffusion method following AdebayoTayo $\mathrm{BC}^{14}$ against the four species of bacterial pathogens coming under two genus. The diameter of inhibition zone was measured and tabulated (Table 1). The response of the selected bacteria was understood from the standard chart.

\section{Calculation of multi-resistance index (MAR index)}

The MAR index can be calculated for each isolate separately and can be determined as a/b, where "a" is the number of antibiotics, towards which the isolate is resistant, and " $b$ " is the number of antibiotics, towards which the isolate susceptibility has been checked. The MAR index, which is higher than $0.2(>0.2)$ identifies bacteria isolated from objects with higher risk of contamination, where antibiotics have been often used. The MAR index $\leq 0.2$ identifies strains from the environment, where antibiotics are rarely used or are not used at all. ${ }^{17,18}$

\section{Probiotics culture}

The Probiotics cultures were used for studying their antagonistic behavior against the fish bacterial pathogens were: Lactobacillus acidophilus, Lactobacillus bravis, Lactobacillus casei, Lactobacillus bulgaricus, Lactobacillus fermentum and Lactobacillus delbrukki.

\section{In vitro antagonistic test}

Above Probiotics were checked for their antimicrobial activity against the fish bacterial pathogens using agar well diffusion method following Pannu et al. ${ }^{19}$ Antimicrobial activity of Probiotics against fish pathogens with some modifications. The diameter of zone was calculated and recorded (Table 2).

Table I Antibiogram studies of isolated fish pathogens

\begin{tabular}{llllll}
\hline No & Antibiotics(mcg) & $\begin{array}{l}\boldsymbol{A} \text {. } \\
\text { sobria }\end{array}$ & $\begin{array}{l}\boldsymbol{A} \text { hydrophila } \\
\text { hy }\end{array}$ & $\begin{array}{l}\text { damsala } \\
\text { datacin }\end{array}$ \\
\hline 1 & Amikacin & $\mathrm{R}$ & $\mathrm{MS}$ & $\mathrm{S}$ & $\mathrm{R}$ \\
2 & Amoxcillin & $\mathrm{R}$ & $\mathrm{R}$ & $\mathrm{R}$ & $\mathrm{R}$ \\
3 & Ampicillin & $\mathrm{R}$ & $\mathrm{R}$ & $\mathrm{R}$ & $\mathrm{R}$ \\
4 & Carbenicillin & $\mathrm{R}$ & $\mathrm{R}$ & $\mathrm{R}$ & $\mathrm{R}$ \\
5 & Cefamandole & $\mathrm{R}$ & $\mathrm{R}$ & $\mathrm{R}$ & $\mathrm{R}$ \\
6 & Cefazolin & $\mathrm{R}$ & $\mathrm{R}$ & $\mathrm{R}$ & $\mathrm{R}$ \\
7 & Cefixime & $\mathrm{R}$ & $\mathrm{R}$ & $\mathrm{MS}$ & $\mathrm{R}$ \\
8 & Chlromphenicol & $\mathrm{R}$ & $\mathrm{R}$ & $\mathrm{MS}$ & $\mathrm{S}$ \\
9 & Ciprofloxacin & $\mathrm{R}$ & $\mathrm{R}$ & $\mathrm{R}$ & $\mathrm{R}$ \\
10 & Doxycycline & $\mathrm{MS}$ & $\mathrm{MS}$ & $\mathrm{R}$ & $\mathrm{MS}$ \\
11 & Erythromycin & $\mathrm{R}$ & $\mathrm{R}$ & $\mathrm{R}$ & $\mathrm{R}$ \\
12 & Framtomycin & $\mathrm{R}$ & $\mathrm{R}$ & $\mathrm{R}$ & $\mathrm{R}$ \\
13 & Galtifloxcin & $\mathrm{MS}$ & $\mathrm{MS}$ & $\mathrm{MS}$ & $\mathrm{MS}$ \\
14 & Gentamycin & $\mathrm{R}$ & $\mathrm{S}$ & $\mathrm{MS}$ & $\mathrm{R}$ \\
15 & Kanamycin & $\mathrm{R}$ & $\mathrm{R}$ & $\mathrm{R}$ & $\mathrm{R}$ \\
16 & Levofloxcin & $\mathrm{S}$ & $\mathrm{S}$ & $\mathrm{S}$ & $\mathrm{S}$ \\
17 & Methicillin & $\mathrm{R}$ & $\mathrm{R}$ & $\mathrm{R}$ & $\mathrm{R}$ \\
18 & Neomycin & $\mathrm{R}$ & $\mathrm{MS}$ & $\mathrm{R}$ & $\mathrm{R}$ \\
19 & Novomycin & $\mathrm{R}$ & $\mathrm{R}$ & $\mathrm{R}$ & $\mathrm{R}$ \\
20 & Ofloxacin & $\mathrm{MS}$ & $\mathrm{R}$ & $\mathrm{R}$ & $\mathrm{R}$ \\
\hline
\end{tabular}

Table 2 Antimicrobial activity of probiotics against fish pathogens

\begin{tabular}{|c|c|c|c|c|c|c|c|c|c|c|c|c|c|}
\hline \multirow[t]{2}{*}{ S.No } & \multirow[t]{2}{*}{ Probiotics } & \multicolumn{3}{|c|}{ A. hydrophila } & \multicolumn{3}{|c|}{ A. sobria } & \multicolumn{3}{|c|}{ V. damsala } & \multicolumn{3}{|c|}{ V. Cholarae } \\
\hline & & $10 \mu \mathrm{l}$ & $20 \mu \mathrm{l}$ & $30 \mu \mathrm{l}$ & $10 \mu \mathrm{l}$ & $20 \mu \mathrm{l}$ & $30 \mu \mathrm{l}$ & $10 \mu \mathrm{l}$ & $20 \mu \mathrm{l}$ & $30 \mu \mathrm{l}$ & $10 \mu \mathrm{l}$ & $20 \mu \mathrm{l}$ & $30 \mu \mathrm{l}$ \\
\hline 1 & L. acidophilus & - & - & + & & - & + & - & - & - & - & - & _- \\
\hline 2 & L. bravis & - & - & - & & - & - & - & - & - & - & - & + \\
\hline 3 & L. casei & - & - & + & & - & + & - & - & + & - & - & + \\
\hline 4 & L. bulgaricus & - & - & - & & - & - & - & - & + & - & - & - \\
\hline 5 & L. fermentum & - & - & + & & - & + & - & - & + & - & - & + \\
\hline 6 & L. delbrukki & - & - & _ & & - & _- & - & - & _ & - & - & + \\
\hline
\end{tabular}




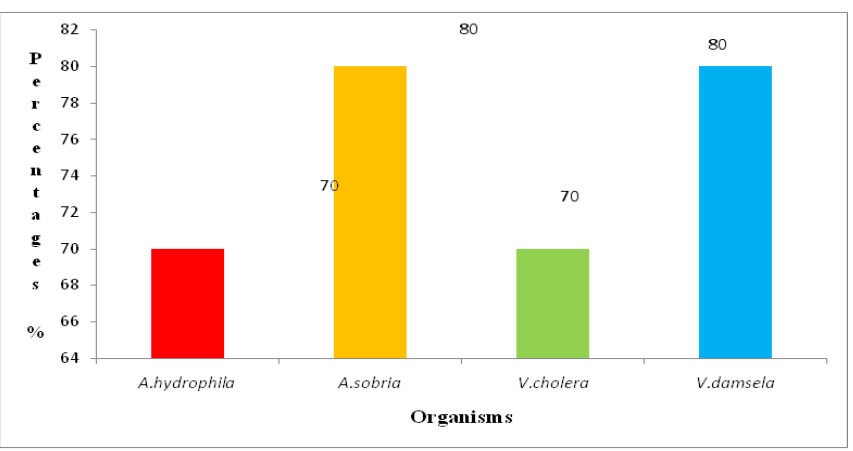

Figure I Antibiotic resistance percentages \%.

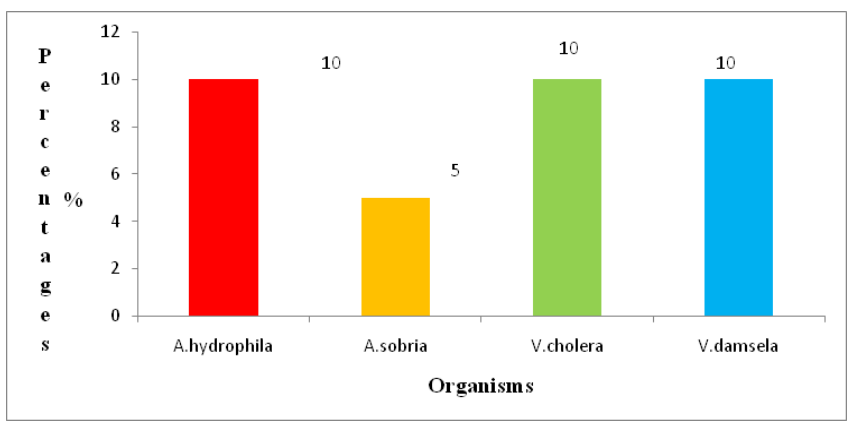

Figure 2 Antibiotics sensitivity chart (\%).

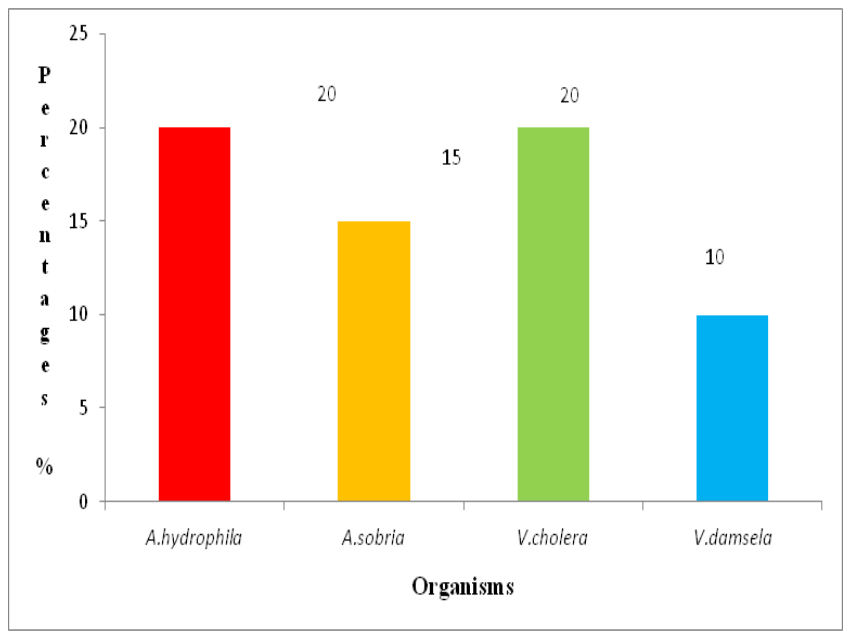

Figure 3 Antibiotics moderate-sensitive chart (\%).

\section{Screening the effect of selected herbs}

Plant extraction: Herbal plants viz., Acalypha indica, Lawsonia inermis, Punica granatum, Vitexnegundo, Catharanthusrosiensis, Psidium guajava, Terminalia Arjuna, Ocimum sanctum and Annona squamosa were collected from different locations of Tirunelveli District of Tamil Nadu, India. Leaves were dried, powdered and macerated with $95 \%$ methanol $(1: 5 \mathrm{w} / \mathrm{v})$ and kept at room temperature for 7 days. The filtrates of each species were removed under vacuum at $40^{\circ} \mathrm{C}$ using a rotary evaporator and the crude methanol extract were stored at $4{ }^{\circ} \mathrm{C}$ and were used for further studies. ${ }^{20}$
Bioassay: The antibacterial test was carried out using the agar diffusion method. The test organisms were inoculated on Muller Hinto nagar plates and were spread uniformly with the aid of sterile glass spreader. Wells of $4 \mathrm{~mm}$ diameter was made on nutrient agar by the use of sterile cork borer. To each well, different concentrations of $(10 \mu 1,20 \mu 1$ and $30 \mu 1)$ crude extracts of leaves were introduced. The plates were inoculated at $37^{\circ} \mathrm{C}$ for $24 \mathrm{~h}$. The inhibitory zones were recorded.

\section{Results and discussion}

\section{Isolation of Aeromonas sp and Vibrio sp}

Presence of Aeromonas $s p$ and Virbio sp was noted in the test fish procured from the Tuticorin market. The organisms picked up from the selective plates based on manufacturer guidelines were confirmed as Aeromonassp, and Vibrio sp, through microbiological and biochemical testings (Table 3). Further identification revealed the presence of 4 species under the 2 genus. The identified species were $A$. hydrophila, A. sobria, and V. cholerae, V. damsela.

\section{Haemolytic activity}

The virulence factor deciding pathogencity of the fish pathogens was analysed by Haemolytic activity. All the four bacterial species were found to be positive for the Haemolytic activity (Table 4).

\section{Uptake of Congo red dye: \\ Uptake of Congo red dye}

The virulence factor deciding pathogenicity of the fish pathogens were analysed by Congo red dye uptake. All the four bacterial species were found to be positive for the Congo red dye uptake performed showing the distribution of virulent factors (Table 4).

\section{Antibiogram analysis}

Antibiotic susceptibility pattern, in the four recovered gram negative bacterial species belonging to Aeromonas sp and Vibrio sp was checked against 20 antibiotics coming under different chemicals and showing diverse mode of action. Kirby-Bauer method was employed for determining the efficacy of selected antibiotics. A mixed response was noted in all the four species tested. Table $1 \&$ Table 5 exploring the effect of antibiotics and percentage of resistance developed in the bacteria. The minimum percent of resistance was 70 and the maximum percent was 50. Percentage of resistance was found to be similar between $A$. sobria and $V$. cholerae. The low range of resistance was noted in $A$. hydrophila and $V$. damsela. Even though an uniformity was noted in the percentage of resistance between $A$. sobria and $V$. cholerae at the higher range and $A$.hydrophila and $V$ damsela $\mathrm{t}$ the low range, A difference in the nature of antibiotics to which resistant developed was noted in the organisms. A. sobria has shown resistant development against (Amikacin, Amoxicillin, Ampicillin, Carbenicillin, Cefamandole, Cefazolin, Cefixime, Chlromphenicol, Ciprofloxacin, Erythromycin, Framtomycin, Gentamycin, Kanamycin, Methicillin, Neomycin and Novomycin). A. hydrophila also exhibited antibiotic resistance against Amoxicillin, Ampicillin, Carbenicillin, Cefamandole, Cefazolin, Cefixime, Chlromphenicol, Ciprofloxacin, Erythromycin, Framtomycin, Kanamycin, Methicillin, Novomycin and Ofloxacinas A. sobria. In addition to that, resistance was noted for these antibiotics. V. damsela has shown resistant development against Amoxcillin, Ampicillin, Carbenicillin, Cefamandole, Cefazolin, Ciprofloxacin, 
Erythromycin, Framtomycin, kanamycin, Methicillin, Novomycin, Neomycin and Novomycin antibiotics. $V$. cholerae has also exhibited antibiotic resistance against Amikacin, Amoxcillin, Ampicillin, Carbenicillin, Cefamandole, Cefazolin, Cefixime, Ciprofloxacin, Erythromycin, Framtomycin, Galtifloxcin, Methicillin, Novomycin, Neomycin, Ofloxacin antibiotics as $V$. damsela. In addition to that resistance was noted for these antibiotics. Resistant development against Ampicillin, Carbenicillin, Cefamandole, Cefazolin, Cefixime, Ciprofloxacin Erythromycin, Framtomycin, Novomycin was noted in A. hydrophila, A. sobria cholerae and V. damsala. Intermediate effect was shown by Doxycycline, Galtifloxcin, and Ofloxacin in A. sobria. Amikacin, Doxycycline, Galtifloxcin, Neomycin in A.hydrophila. Cefixime, Chloramphenicol, Galtifloxcin, Gentamycin in $V$. damsela. Doxycycline, Galtifloxcin V. cholerae. Levofloxacin was found to be effective over all the four species tested. All the other 19 antibiotics were found to inhibit only $25 \%$ of the organism employed tested.

\section{Calculation of multi-resistance index (Mar Index)}

MAR index of the organism against the tested antibiotics was shown in the [Table 5]. The antibiotics could be considered effective only if the MAR index value is below 0.2. Buts MAR index value above 0.70 indicating the threat from the organisms as for as antimicrobial resistance is concerned. Table 6 also observed over $V$. damsela. A similar percentage of effect was noted with Psidium guajava as in Vishakudini but it did not show activity over A. hydrophila. $V$. cholerae was inhibited by the methanol extract of T.arjuna. C.rosiensis, has inhibited both the species of Aeromonas and Vibrio were tested.

\section{Antibacterial analysis of herbal extracts}

Methanol extract of the leaf collected from 9 herbs including Acalypha indica, Lawsonia inermis, Punica granatum, Vitexnegundo,
Catharanthusrosiensis, Psidium guajava, Terminalia arjuna, Ocimum sanctum and Annona squamosa was checked at 3 different concentration such as $10 \mu \mathrm{l}, 20 \mu \mathrm{l}$ and $30 \mu \mathrm{l}$ by agar well diffusion method. DMSO was used as negative control. A meager activity was noted at the selected range of concentrations in all the herbs tested but notable effect over the pathogens was noted at $30 \mu$ concentrations. Among the notable inhibitory effect, highest effect was noted for $P$. guajava $30 \mu 1$ concentrations against $V$. damsela and lowest efficacy was noted with all the tested 10plants (Table 7). Both $V$. cholerae and $V$.damsela were found to be sensitive for the leaf extract of $P$. guajava at $30 \mu \mathrm{l}$ concentrations against $V$. damsela and lowest efficacy was noted with all the tested 10 plants (Table 7). Both V. cholerae and $V$. damsela were found to be sensitive for the leaf extract of Psidium guajava at $30 \mu$ concentration. The methanol extract of Vishakudini was able to inhibit $75 \%$ of the organisms taken but a meagre effect was also observed over $V$. damsela. A similar percentage of effect was noted with Psidium guajava as in Vishakudini but it did not show activity over A. hydrophila. V. cholerae was inhibited by the methanol extract of T. Arjuna. C. rosiensis has inhibited both the species of Aeromonas and Vibrio were tested.

\section{Effect of probiotics}

The bacteriocin source (supernatant) prepared from 6 Lactobacillus sp., Lactobacillus acidophilus, Lactobacillus bravis, Lactobacillus casei, Lactobacillus bulgaricus, Lactobacillus fermentum and Lactobacillus delbrukki. was checked for its antibacterial effect such as $10 \mu 1,20 \mu 1$ and $30 \mu 1$ concentrations against fish bacterial pathogens by agar well diffusion method. Table 7 helped us to understand that the effectiveness of bacteriocin was inferior compared to the effect of herbs but a tiny inhibitory effect was noted at $30 \mu 1$ concentrations only with some sources.

Table 3 Biochemical test for fish pathogens

\begin{tabular}{llllll}
\hline & & Results & & & \\
\cline { 2 - 6 } No & Tests & A. hydrophila & A. sobria & V. cholerae & V. damsela \\
\hline 1 & Gram's staining & - & - & - & + \\
2 & Indole & - & + & + & + \\
3 & Methyl red & + & + & + & + \\
4 & Voges-Proskauer & - & + & + & + \\
5 & Citrate & + & + & + & + \\
6 & Catalase & + & + & - & + \\
7 & Oxidase & + & + & + & + \\
8 & Nitrate reduction & + & + & + & + \\
9 & Gas from glucose & + & + & + & + \\
10 & Glucose fermentation & + & + & + & + \\
11 & TSI & + & + & + & + \\
13 & Arginine decarboxylase & + & + & + & + \\
14 & Lysine decarboxylase & + & + & + & + \\
15 & Ornithine decarboxylase & + & + & + & + \\
16 & Salicin fermentation & + & + & + & + \\
17 & Leuicine decarboxylase & + & + & - & + \\
18 & Lysine decarboxylase & + & + & + & + \\
19 & Valine decarboxylase & + & + & + & + \\
21 & Nacl0\% & + & + & + & + \\
22 & Nacl 1\% & + & + & - & + \\
23 & Nacl 3\% & + & - & - & - \\
24 & Nacl 6\% & + & + & + & + \\
25 & Nacl 8\% & - & + & + & + \\
26 & Nacl 10\% & - & + & + & + \\
\hline
\end{tabular}


Table 4 Phenotypic determination of virulence factors

\begin{tabular}{llll}
\hline No & Organisms & Haemolytic activity & Congo red uptake \\
\hline 1 & A. hydrophila & + & + \\
2 & A. sobria & + & + \\
3 & V. cholerae & + & + \\
4 & V. damsela & + & + \\
\hline
\end{tabular}

Table 5 Mar Index and Resistance Limits of Isolates of Aeromonas sp and Vibrio Sp

\begin{tabular}{lllll}
\hline NO & Organisms & Source & Resistance limits & MAR index \\
\hline 1. & A. Hydrophila & Fish & 14 & 0.70 \\
2. & A. sobria & Fish & 16 & 0.80 \\
3. & V. damsela & Fish & 14 & 0.70 \\
4. & V. Cholerae & Fish & 16 & 0.80 \\
\hline
\end{tabular}

Table 6 Antibacterial analysis of herbal extracts

\begin{tabular}{|c|c|c|c|c|c|c|c|c|c|c|c|c|c|}
\hline & \multirow{2}{*}{ Plant extract } & \multicolumn{3}{|c|}{ A. sobria } & \multicolumn{3}{|c|}{ A. hydrophila } & \multicolumn{3}{|c|}{ V. damsela } & \multicolumn{3}{|c|}{ V. cholarae } \\
\hline & & $10 \mu \mathrm{l}$ & $20 \mu \mathrm{l}$ & $30 \mu l$ & $10 \mu \mathrm{l}$ & $20 \mu l$ & $30 \mu l$ & $10 \mu \mathrm{l}$ & $20 \mu l$ & $30 \mu l$ & $10 \mu \mathrm{l}$ & $20 \mu \mathrm{l}$ & $30 \mu \mathrm{l}$ \\
\hline 1 & Lawsonia inermis & $3 \mathrm{~mm}$ & $4 \mathrm{~mm}$ & $5 \mathrm{~mm}$ & - & - & - & - & $\mathrm{mm}$ & $\mathrm{mm}$ & - & - & - \\
\hline 2 & Punica granatum & + & + & + & - & - & + & $2 \mathrm{~mm}$ & $3 \mathrm{~mm}$ & $4 \mathrm{~mm}$ & - & $2 \mathrm{~mm}$ & $3 \mathrm{~mm}$ \\
\hline 3 & Annonasquamosal & - & + & + & - & - & - & - & $2 \mathrm{~mm}$ & $3 \mathrm{~mm}$ & - & + & + \\
\hline 4 & Vitexnegundo & + & $2 \mathrm{~mm}$ & $3 \mathrm{~mm}$ & - & - & - & $2 \mathrm{~mm}$ & $3 \mathrm{~mm}$ & $4 \mathrm{~mm}$ & - & + & $5 \mathrm{~mm}$ \\
\hline 5 & Catharanthusrosiensis & + & + & $2 \mathrm{~mm}$ & + & $3 \mathrm{~mm}$ & $5 \mathrm{~mm}$ & - & + & + & $3 \mathrm{~mm}$ & $5 \mathrm{~mm}$ & $6 \mathrm{~mm}$ \\
\hline 6 & Psidium guajava & - & + & + & - & $2 \mathrm{~mm}$ & $3 \mathrm{~mm}$ & $5 \mathrm{~mm}$ & $6 \mathrm{~mm}$ & $8 \mathrm{~mm}$ & $3 \mathrm{~mm}$ & $5 \mathrm{~mm}$ & $7 \mathrm{~mm}$ \\
\hline 7 & Terminalia arjuna & - & - & + & $2 \mathrm{~mm}$ & $3 \mathrm{~mm}$ & $5 \mathrm{~mm}$ & $3 \mathrm{~mm}$ & $5 \mathrm{~mm}$ & $6 \mathrm{~mm}$ & - & - & + \\
\hline 8 & Ocimum sanctum & - & - & - & - & - & - & $2 \mathrm{~mm}$ & $3 \mathrm{~mm}$ & $4 \mathrm{~mm}$ & - & + & + \\
\hline 9 & Acalypha indica & - & + & + & - & - & - & + & 3 & 4 & - & - & - \\
\hline 10 & Vishakudini & - & $2 \mathrm{~mm}$ & $3 \mathrm{~mm}$ & $2 \mathrm{~mm}$ & $3 \mathrm{~mm}$ & $5 \mathrm{~mm}$ & $4 \mathrm{~mm}$ & $5 \mathrm{~mm}$ & $7 \mathrm{~mm}$ & - & + & + \\
\hline
\end{tabular}

Table 7 Antibacterial activity test results (Percentages \%)

\begin{tabular}{lllll}
\hline & Organisms & $(\mathrm{R}) \%$ & $(\mathrm{~S}) \%$ & $(\mathrm{MS}) \%$ \\
\hline 1 & A. Hydrophila & 70 & 10 & 15 \\
2 & A. sobria & 80 & 5 & 20 \\
3 & V. damsela & 80 & 10 & 10 \\
4 & V. Cholerae & 70 & 10 & 20 \\
\hline
\end{tabular}

$R$, resistance; $S$, sensitive; $M S$, moderate sensitive

\section{Discussion}

Asian aquaculture is characterized by an enormous diversity of species, with several dozen marine and freshwater species being farmed. ${ }^{21}$ Diseases are one of the crucial factors affecting aquaculture. Antibiotics and chemotherapy have been used to prevent disease outbreaks and control proliferation of pathogens for a long time, causing the emergence of drug-resistant bacteria. Presently, although a good number of antibiotics such as norfloxacin, ciprofloxacin, oxytetracycline, gentamicin, chloramphenicol ${ }^{22}$ Cefazolin $^{23}$ and aztreonam ${ }^{24}$ etc. are employed for controlling the infection in fishes. Analysis of virulence helps us to declare the pathogenic nature of bacteria. Various virulence factors are associated with pathogens including hemolytic activity, uptake of Congo red dye. ${ }^{18}$ All the four isolates were found to be virulence based on the positive results obtained in 2 tests performed. The role of Haemolytic activity and Uptake of Congo red dye in determining the virulence has been supported by so many workers. These have their own disadvantages such as the development of disease-resistant strains; carry over, high cost and dose problems as well as indiscriminate use by aqua farmers. Antibiotic resistance developed in fish pathogens of one species could be transferred to the member of other species belonging to the same genus or different genus. If the resistance is developed in a fish pathogen which could also affect human or the developed resistance is transferred to the human pathogens, then it will complicate the situation. Thus more attention is given across the world to study the 
antibiotic resistance development among fish pathogens. Aermonas sp and Vibrio are the two Gram negative bacteria affecting both fish and human. Association of the above two organisms with diseases of aquatic animals have been documented by many workers. ${ }^{18}$ Development of multi-drug resistance had been checked in the current study against 20 antibiotics falling under different chemical grouping revealed development of MDR in all the four species tested [Table 5]. In both the genus, the minimum $\%$ of antibiotic resistance was $70 \%$ and the maximum was $80 \%$. The MDR index is above 0.7 it cautions us the possibility of resistance gene transfer into other pathogens. Pannu R et al. ${ }^{19}$ has documented resistance development in fish pathogens including Aeromonassp against nitrofurantoin, amoxycillin, bacitracin, cephalothin, erythromycin, novobiocin, vancomycin, ampicillin, oxacillin and colistin. The danger of antibiotic resistance in fish bacterial pathogens have also been proved..$^{25-26}$ Thus, the overuse of antibiotics and other chemicals needs to be checked and the use of alternative methods should be stressed.

The demands for chemicals antibiotics free aquaculture product production have been on raise. Probiotics and plants are the major choice for fighting against diseases affecting aquatic animals in addition to other remedial measures such as immunostimulants. ${ }^{27}$ Methanol extract of nine plants including Vishakudini was checked at three concentrations such as 10,20 and 30ul and found effectiveness at $30 \mathrm{ul}$ in P. guajava and against the pathogens tested. Methanol extract has also been used to assess the effectiveness of herbs over fish pathogens by Abdullah Mann et al. ${ }^{28}$

Pannu R et al. ${ }^{19}$ reported the antagonistic efficacy of four plants viz. Azadirachta indica, Aloe barbadensis, Withania somnifera, Momordica charantia was evaluated against fish bacterial pathogens. An effective inhibition was observed for all the four plants. But in the current study, effectiveness was noted only in 2 out 9 herbs. Vishakudini is one of the two drugs showing effectiveness. Vishakudini is the mixture of different herbs normally used by local public to arrest the infections of various origins. To our knowledge no work has been done explaining the efficacy of this herbal mixture.

Plants have been used as traditional medicine since time immemorial to control bacterial, viral and fungal diseases. Treatment of bacterial diseases with different herbs has been safely used in organic agriculture, veterinary, human medicines and aquaculture with potent antimicrobial properties. ${ }^{6}$ Medicinal plants as alternative agents are effective to treat infectious disease and mitigate any of side effects that are associated with synthetic antimicrobials. Plants like Azadirachta indica, Cinnmommum verum, Eupatorium odoratum, Solanum torvum, Curcuma longa, Datura metel, Aloe barbadensis, Nuphar lutea, Nymphaea alba, Gynista Lydia, Phyllanthus niruri, Cynodondactylon, Calotropis gigantean Withania somnifera, Vinca minor, Momordica charantia, Fragaria Vesca Have potential for being effective herbal drugs against the fish and other aquaculture pathogens. ${ }^{6}$ Plant or herbal extract have minimal side effects, easily biodegradable, inexpensive and extracts can be easily prepared. Plants generally produce many secondary metabolites i.e. tannins, alkaloids and flavonoids which constitute an important source of inhibiting many pathogens. Identification and characterization of such metabolites with antimicrobial activities is very important. The usage of heavy antibiotics in aquaculture field needs to be reduced and replaced with alternative processes.
Therefore, different researchers suggested the alternative to the nonpathogenic strains of bacteria in the form of Probiotics can be applied in fish disease prevention and control. ${ }^{11}$ Fuller, reported that probiotic preparations may be made up of a single strain or may contain mixture up to eight strains. The advantage of multiple strain preparations is that they have more sensitivity towards pathogens and active against different aquaculture animals. The probiotic preparation includes a combination of bacterial strains viz. Lactobacillus bulgaricus, Lactobacillus plant arum, Streptococcus thermophillus, Enterococcus faecium, Enterococcus faecalis, Bifidobacterium $s p$ and Escherichia coli $^{29}$ isolated probiotic organisms, Bifidobacterium sp., Lactobacillus sp. and $S$. cerevisiae from soil, curd and yeast pellets and was that Bifidobacterium sp. had the high inhibitory effect against Salmonella sp supporting that single Probiotics are also effective against bacterial pathogens. In the current study six Lactobacillus sp have been used individually and noted a meagre effectiveness at least against any one of the four species of pathogens tested at $30 \mathrm{ul}$ concentration of its supernatant when tested at three concentrations including 10,20 and $30 \mathrm{ul}$. But $L$. casei was able to inhibit all the four pathogens tested at $30 \mathrm{ul}$ concentration. Lactobacillus sp has been the choice of probiotic in aquaculture because of several positive features such as GRAS, its role in digestion through the production of lactic acid, competition for adhesive sites, production of vitamins etc., These probiotic bacteria suppress proliferation of pathogenic and opportunistic bacteria in the mucus in intestine as well as ambient environment of the fishes simultaneously. ${ }^{30}$ Consequently the probionts reduce the incidence of diseases. Tejpal ${ }^{31}$ successfully eliminated Aeromonas sp using probiotic bacteria.

Probiotic strains of $V$. alginolyticus found very effective in reducing disease caused by the $A$. salmonicida, $V$. anguillarum and $V$. ordalli in aquatic animals. A culture of $V$. alginolyticus with Chaetoceros meulleri is also used as a potent Probiotics. ${ }^{32} \mathrm{~A}$ similar study was conducted in shrimp farming, in which a marine strain of Pseudomonas was found to inhibit pathogenic Vibrio bacteria. ${ }^{33}$

In the current study, Role of Lactobacillus sp and herbs like Psidium guajava and Vishakudini in the control of Aeromonas sp and Vibrio sp have been proved. Further works have to be carried out to determine the exact concentration and the mode of application of these probiotic and herbs. The combined effect of these two has also to be checked.

\section{Conclusion}

The finding of the present work revealed the presence of MDR at a high frequency in both the genus tested. It could be considered as a serious issue because there is a bright and great possibility for the transfer of resistance genes to other bacterial pathogens affecting human beings and could bring difficulty in treating the diseases. The findings also insists an urgent need to accelerate research on the development of practically possible, effective, reliable and low cost herb and probiotic based disease management strategies.

\section{Acknowledgements}

None.

\section{Conflict of interest}

The author declares no conflict of interest. 


\section{References}

1. Milatovic D, Braveny I. Development of resistance during antibiotic therapy. Eur J Clin Microbiol. 1987;6(3):234-244.

2. Fish DN, Piscitelli SC, Danziger LH. Development of resistance during antimicrobial therapy: a review of antibiotic classes and patient characteristics in 173 studies. Pharmacotherapy. 1995;15(3):279-291.

3. Chugh TD. Emerging re-emerging bacterial diseases in India. $J$ Biosci. 2008;33(4):549-555.

4. Ravikumar S, Gnanadesigan M, Suganthi P, Ramalakshmi A, (2010) Antibacterial potential chosen mangrove plants against isolated urinary tract infectious bacterial pathogens. Int J Med and Med Sci 2(3): 94-99

5. Yin G, Ardo L, Jeney Z, et al. Chinese herbs (Loonier japonica and Ganoderma lucidum) enhance non-specific immune response of tilapia, oreochromisniloticus, and protection against Aeromonas hydrophila. In: Bondad-Reantaso MG, et al. editors. Diseases in Asian Aquaculture VI. Fish Health Section, Manila, Philippines: Asian Fisheries Society; 2008. $505 \mathrm{p}$.

6. Pandey G, Sharma M, Mandloi AKan Shani YP. Antimicrobial activity of some medicinal plants against fish pathogens. Int Res J Pharma. 2012;3(4):28-30

7. Meyer FP. Aquaculture Disease and Health Management. J Anim Sci. 1991;69(10):4201-4208.

8. Ahmad I, Mehmood Z, Mohammad F. Screening of some Indian medicinal plants for their antimicrobial properties. J Ethnopharmacol. 1998;62(2):183-193.

9. Evans CE, Banso A, Samuel OA. Efficacy of some nupe medicinal plants against Salmonella typhi: an in vitro study. J Ethnopharmacol. 2000;80(1):21-24.

10. Lim HJ, Kapareiko D, Schott EJ, et al. Isolation and evaluation of new probiotic bacteria for use in shellfish hatcheries: isolation and screening for bioactivity. J Shellfish Res. 2011;30(3):609-615.

11. Fuller R. Probiotics in man and animals - A review. J Appl Bacteriol. 1989;66(5):365-378.

12. Pinto AD, Circcarese G, Corato RD, et al. Detection of pathogenic Vibrio parahaemolyticus in Southern Italian shellfish. Food Control. 2008;19(11):1037-1041.

13. Arunagiri K, Jayashree K, Sivakumar T. Isolation and identification of Vibrios from marine food resources. Int J Curr Microbiol App Sci. 2013;2(7):217-232

14. Adebayo-Tayo BC, Okonko IO, Esen CU, et al. Incidence of potentially pathogenic Vibrio spp. In fresh seafood from itu creek in Uyo, Akwalbom State, Nigeria. World Applied Sciences Journal. 2011;15(7):985-991.

15. Laith AR, Najiah M. Aeromonas hydrophila: antimicrobial susceptibility and histopathology of isolates from diseased catfish, clariasgariepinus (Burchell). J Aquac Res Development. 2013;5:215.

16. Sarker MA, Chowdhury MBR, Rahman MM. et al. Pathogenicity and Antibiotic Resistance of Some Aeromonas hydrophila isolates. Bangladesh J Fish. 1998;21(2):61-64.

17. Krumperman PH. Multiple antibiotic indexing of E. coli to identify highrisk sources of fecal contamination of foods. Appl Environ Microbiol. 1983;46(1):165-170
18. Orozova P, Chikova VH, Najdenski H. Antibiotic resistance of pathogenic for fish isolates of Aeromonas spp. Bulg J Agric Sci. 2010;16:376-386.

19. Pannu R, Dahiya S, Sabhlokumar AP, et al. Effect of Probiotics, antibiotics and herbal extracts against fish bacterial pathogens. Ecotoxicol Environ Contam. 2014;9(1):13-20.

20. Haniffa MA, Kavitha K. Antibacterial activity of medicinal herbs against the fish pathogen Aeromonas hydrophila. J Agri Technol. 2012;8(1):205211.

21. Hari krishnan R, and Balasundaram C. In vitro and in vivo studies of the use of some medicinal herbals against the pathogen Aeromonas hydrophila in goldfish. J Aquat Anim Health. 2008;20(3):165-176.

22. Sahoo PK, Mukherjee SC. In-vitro susceptibility of three bacteria pathogens of catfish to 23 antimicrobial agents. Indian J Fisheries. 1997;44(4):393-397.

23. Zhang XJ, Fang $\mathrm{H}$, Chen $\mathrm{CZ}$, et al. Sensitivity of pathogenic Edwardsiellatarda isolated from flounder (Paralichthysolivaceus) to some antimicrobial agents. Fish Sci. 2005;24:15-18.

24. Zhu ZC, Shi XG, Zhang Sj, et al. The pathogenic bacteria of the as cites in Japanese flounder (Paralichthysolivaceus). Fish Sci. 2006;7:325-329.

25. Saleh MY Al-Othrubi, Cheah Yoke Kquee, Hamed Mirhosseini, et al. Antibiotic Resistance of Vibrio parahaemolyticus Isolated from Cockles and Shrimp Sea Food Marketed in Selangor, Malaysia. Clin Microbial. 2014;3:148.

26. Nguyen HN, Van TT, Nguyen HT, et al. Molecular characterization of antibiotic resistance in Pseudomonas and Aeromonas isolates from catfish of the Mekong Delta. Vet Microbiol. 2014;171(3-4):397-405

27. SajidMaqsood, Prabjeet Singh, Munir Hassan Samoon, et al. Emerging role of immunostimulants in combating the disease outbreak in aquaculture. Int Aquat Res. 2011;3:147-163.

28. Abdullahi Mann, Yusuf Adamu Kuta. Antibacterial activity of methanolic extracts of Terminalia avicennioides against fish pathogenic bacteria. American Journal of Research Communication. 2014;2(4):133-146.

29. Venkatesan S, Kirithika M, Roselin L, et al. Comparative in vitro and in vivo study of three probiotics organisms, Bifidobacterium $\mathrm{sp}$, Lactobacillus sp, $S$. cerevisiae and analyzing its improvement with the supplementation of probiotics. Int J Plant Animal Enviorn Sci. 2012;2(2):94-106.

30. Balcazar JL, Blas I, Ruiz-Zarzuela I, et al. The role of probiotics in aquacultures. Vet Microbiol. 2006;(3-4):173-186.

31. Tejpal, Dahiya, Ravi Kant Verma, et al. Elimination of pathogenic bacterium. Aeromonas hydrophila by the use of Probiotics. 2012;6(3):209214.

32. Gomez-Gil B, Roque A Velasco-Blanco G. Culture of Vibrio alginolyticus, a potential probiotic bacterium, with the microalga Chaetocerosmuelleri. Aquaculture. 2002;211(1-4):43-48.

33. Chythanya R, Karunasagar I, Karunasagar I. Inhibition of shrimp pathogenic vibrios by a marine Pseudomonas I-2 strain. Aquaculture. 2002;208(1-2):1-10. 